\title{
Physicians sue pharmacy chain for unfair competition
}

Two Montréal-area doctors are suing a prominent pharmacy chain for allegedly creating unfair competition by attempting to attract doctors to locate their clinics near its stores.

The physicians also accuse the Quebec College of Physicians, named as a co-defendant, of failing to take action to stop violations of the doctors' code of ethics.

Dr. Daniel Poulin claims representatives from Jean Coutu

t Group Inc. offered him \$500 000 to re-locate his medical clinic above a new pharmacy the chain was building in the South Shore community of St. Constant. The civil action claims Jean Coutu offered Poulin a rental price per square foot that was less than half the amount he was paying elsewhere.

The statement of claim, filed in Quebec Superior Court under the Competition Act, also argues that direct and indirect subsidies and other incentives that the pharmacy chain allegedly used constitute unfair business practices. It blames those practices for the closure of several medical clinics, including 1 owned by Dr. Robert Perron, the co-plaintiff.

Both the Quebec College and the Jean Coutu Group declined comment.

The lawsuit maintains that the alleged benefits offered doctors run contrary to the pharmacists' and the physicians' codes of ethics. "When the College says discounted rent is not a conflict of interest, it's false," Poulin told CMA7. "The definition of a conflict of interest includes the appearance [of conflict]."

A pharmacy is also suing physicians. Pharmacist Sandrine Vinet launched a lawsuit against the Médicentre LaSalle clinic claiming that the departure of more than half the doctors from the medical office last summer significantly decreased the number of prescriptions her pharmacy filled.

Dr. Clifford Blais, who owns the medical clinic and rents space to the pharmacy, told $\mathrm{La}$ Presse the legal action is unfounded. There was no deal between his clinic and the pharmacy about clientele, Blais said. - Brenda Branswell, Montréal

\section{Pharmaceutical Industry}

\section{Lawsuits mount in wake of rofecoxib (Vioxx) withdrawal}

Within 2 weeks of Merck \& Co.'s decision to withdraw the anti-arthritis drug rofecoxib (Vioxx) because of its cardiovascular risks, lawyers filed 10 class-action lawsuits collectively representing several thousand plaintiffs in Canada against the firm and its Canadian subsidiary, Merck Frosst Canada (CMA7 2004;171[7]:1027-8).

Four suits were filed in Ontario, 2 in Quebec, and 1 each in BC, Saskatchewan, Manitoba and Newfoundland and Labrador. A 7-province action filed in the Federal Court of Canada also named the federal government as co-defendant. More suits are expected in the coming months.

The claims could coalesce into a unified suit, or a bid in a single $\tilde{\sigma}$ province could be certified as a class action and eventually advertise for victims, absorbing under its umbrella all Canadians who claim to have suffered side-effects from rofecoxib, says Tony Merchant of the Regina-based Merchant Law Group.
Merck Frosst Canada public affairs manager Marlene Gauthier declined comment except to say "we believe we have strong and meritorious defences to the lawsuits brought against us."

Although it often takes years for class-action suits to coalesce, lawyers say there's nothing surprising about the alacrity with which they've been filed. Nor will there be a shortage of potential plaintiffs; IMS Health reports that 3.3 million rofecoxib prescriptions worth $\$ 196.6$ million were filled in Canada in 2003. Lawyer Jim Poyner, of Vancouver-based Poyner Baxter, said his firm received 800 complaints from $\mathrm{BC}$ residents within days.

Most suits are against only Merck and its associates, for allegedly failing to undertake adequate safety testing on rofecoxib while continuing to market it. Rofecoxib was withdrawn when preliminary results from the 3year APPROVe (Adenomatous Polyp Prevention on VIOXX)

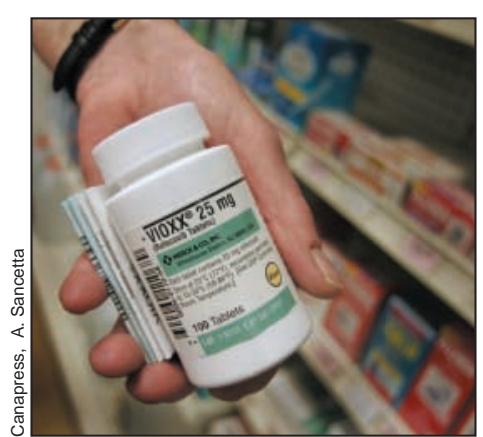

The legal fallout began mere days after rofecoxib was removed from the market Sept. 30 .

trial showed almost double the risk of cardiovascular incidents among trial subjects taking the drug for more than 18 months, compared to patients taking placebo.

Pfizer Inc., manufacturers of the similar COX-2 medication celecoxib (Celebrex), announced Oct. 18 they are starting a clinical trial in 2005 to assess its drug in osteoarthritis patients at high risk for cardiovascular disease. - Wayne Kondro, CMAJ 